\title{
EVALUATION OF CERTAIN EGYPTIAN RICE CULTIVARS TO BLAST DISEASE INCIDENCE DURING FOURTEEN YEARS IN EGYPT. \\ Sehly, M. R. ${ }^{1}$; S.M. El-Wahsh'; M.M. El-Malky²; E. A. S. Badr'; R. A. S. EI-Shafey ${ }^{2}$ and I.R. Aidy ${ }^{2}$ \\ ${ }^{1}$ Rice Pathol. Dept., Plant Pathol. Res., Institute, Agric. Res. Center, ${ }^{2}$ Rice Dept., Field Crops Res. Institute, Agric. Res. Center, Giza, Egypt.
}

\section{ABSTRACT}

The study aimed to evaluate certain commercial Egyptian rice cultivars in both seedling and adult stages to blast disease, identify rice blast hot spots at different rice governorates, and identify effective rice blast resistance genes and common physiological races of Pyricularia grisea under field conditions during 1994 to 2007 seasons. Fourteen Egyptian rice cultivars were tested during the period of study. In addition, ten Japanese differential varieties and two international differential varieties evaluated at three locations i.e. Sakha, Gemmiza and Zarzora were included and tested under natural infection at blast nursery tests.

As for field resistance, the cultivars Giza 171, Giza 172, Giza 176, Giza 159 and Reiho were susceptible during such period, hawever, Reiho cultivar escaped from the disease in some locations in 2005 season. Also, the cultivars Sakha 101 and Sakha 104 were resistant through 1994 up to 2002, except through 1997 up to 1999 , Sakha 104 was infected in one or all locations with 2-4 blast score . Starting from 2003 and 2004, the resistance was broken down in some locations and the cultivars were completely susceptible in 2005 up to 2007 seasons. Giza 181 was infected in some locations in 2004 up to 2007. While, the cultivars Giza 175, Giza 177, Giza 178, Giza 182, Sakha 102 and Sakha 103 achieved complete resistance. On the other hand, these cultivars were transplanted at different locations (multi-location test) (1822 locations yearly) and distributed on demonstration farmers' fields at six rice governorates starting from 1996 up to 2007 rice growing seasons. The results showed that Giza 171, Giza 159, Giza 176 and Reiho were susceptible in most of tested locations. While, Giza 181, Giza 177, Giza 178, Sakha 102, Giza 182 and Sakha 103 were completely resistant in all tested locations during this period. On the other hand, Sakha 101 and Sakha 104 were resistant up to 2003 and became susceptible in $15 \%$ of the tested locations starting from 2004 season. The level of susceptibility increased to 47.6, 85.7 and $72.2 \%$ in 2005; 2006 and 2007 seasons, respectively for Sakha 101 , and increased to $28.6,66.7$ and $44.4 \%$ for Sakha 104 in 2005, 2006 and 2007 seasons, respectively. The resistant genes (Pi-a and Pi-ks) exhibited low levels with 20 and $31 \%$, respectively, while higher levels of Pi-b, Pi-k and Pi-m genes with 90, 85 and $80 \%$ respectively were found during 1994- 1996 seasons. While during 1997 up to 2000 , higher levels of resistant genes $\mathrm{Pi}-\mathrm{Z}$ and pi-k with 95.6 and $93.4 \%$ but Pi-a and Pi-ta genes showed lower levels of resistance with 14.3 and $21.1 \%$, respectively. In the last period (2001-2004) Pi-a and Pi-ta ${ }^{2}$ genes showed low level of resistance with 15 and $25 \%$. The rest genes showed high levels and ranged from $60-95 \%$.

Concerning greenhouse tests, the results showed that IC race group was common race followed by $\mathrm{IB}$ and IG groups while IE, IF, IH and II were rare, However, IH and IG groups were the common races during 1997 up to 2000 period. The third and fourth periods (2001 up to 2006) IG group was the common one and it was specific on Sakha 101 rice cultivar and responsible for its breakdown, followed by IB group which include IB-45 race as a specific race for Sakha 104 and also responsible for its breakdown. 


\section{INTRODUCTION}

Rice is the second most important cereal crop in the world. It constitutes the essential food for over half $(54 \%)$ of the world's population. In Egypt, rice is the second staple food after wheat, and is very important for local consumption, as well as for exportat following cotton crop. In Egypt, rice is annually grown in more than one million feddans, mostly in the Northern part of the Nile Delta. The cultivated area in 2006 season was 1.59 million feddans, that produced about 6 million tons of paddy rice with an average yield of about 10.06 tons / hectare, which is considered one of the highest average yield in the world (Rice National Campaign Report, 2006). However, rice diseases (especially rice blast) reduce rice production by about $5 \%$ in normal or mild infected seasons, while in epidemic seasons, yield losses may reach as high as $30-50 \%$ (Sehly et al 2002).

Rice blast disease, caused by Pyricularia grisea, is one of the most serious biotic stresses in the tropics and subtropics. The most economic and safety way to control this disease is by growing resistant cultivars. Unfortunately, in most cases, the resistance of these cultivars overcomes in few years after cultivar release (Veillet, et al 1996). The major genes, selected to confer a high level of blast resistance, have been rapidly passed by virulent races. Recurrent selection for partial resistance is the most efficient breeding strategy to improve the blast resistance durability of rice cultivars (Notteoghem, 1981). Yamaguchii, et al. (1998) and Shinza Koizumi (2006) reported that blast resistance in rice is classified into two groups: the first group is complete resistance, which is controlled by major genes and called qualitative, race-specific, and about 50 complete resistance genes have been reported with their chromosomal locations. While the second group is known as field resistance, and called quantitative, non-specific and controlled by several genes or polygenic characteristic, which have additive effect. Field resistance is effective and important, because complete resistance is subject to be broken down after some years of variety release. This breakdown is due to the variability of the isolates of blast pathogen under field condition (Ou.1985 and Coley, 1992). Several mechanisms were suggested to explain this variability. Chromosomal variability, proposed by Giatgong and Fredericksen (1969), was demonstrated on lagging chromosomes favoring aneuploidy (Row et al., 1985), while parasexual recombination was demonstrated on a laboratory strain of rice blast pathogen (Crawford et al., 1986). Karyotype analysis using pulse field gel electrophoresis (PFGE) showed that chromosome and mini-chromosome karyotypes were highly variable (Talbot et al., 1993). These small chromosomes could be lost during mitosis supporting the idea of Giatgong and Fredercksen (1969) that chromosomal aberration led to pathotypic variation. Chromosomal abnormalities can be eliminated after recurrent meiosis in the perfect stage sexual recombination, but were generally maintained after several mitoses in the imperfect stage (Kistler and Miao 1992). In addition, presence of transposable element, which is known to affect expression of adjacent genes, may cause rearrangement in the 
genome (Berg and Howe 1989). Sehly et al (1990) evaluated twenty-seven rice entries under field and greenhouse conditions, some entries showed complete resistance under both tests, others were resistant in one test but susceptible in others. They added that field leaf resistance can be partitioned into a few components of slow- blasting resistance such as lesion size or lesion density. Veillet et al (1996) reported that the most economic way for controlling blast disease is by growing resistant cultivars, but unfortunately, in most cases, the resistance of the new cultivars overcome within few years after release, as the major genes selected to confer a high level of blast resistance are rapidly passed by virulent races. Sehly et al (2002) reported that different screening tests during seedling and adult plant stages were valuable in understanding the level and type of resistance of materials under evaluation.. Abo-Youssef and El-Wahsh (2005) found that, out of 30 entries, nineteen and twenty-one entries were resistant to rice blast races, ID-7 and IA-107, respectively. On the other hand, eight and five entries were susceptible, while three and four entries were moderately resistant for the same races. Eizenga et al. (2006) evaluated 91 entries in greenhouse to determine resistance genes $\mathrm{Pi}$-ta and $\mathrm{Pi}-\mathrm{b}$, out of these entries five Egyptian rice entries; Egyptian yasmine, GZ 1368-5-4, GZ 5578-2-1-2, GZ 5594-23-12 and GZ 5830-48-2-2 (sister line of Sakha 103). Both Pi-ta and Pi-b were identified in 37 of the 91 accessions.

The present study aimed to evaluate some commercial Egyptian rice cultivars in both seedling and adult stages to blast disease, identify rice blast hot spots at different rice governorates, and identify effective rice blast resistance genes and common races.

\section{MATERIALS AND METHODS}

\section{1- Field Evaluation:}

\section{A - Blast nursery test:}

Fourteen Egyptian rice cultivars (produced by hybridization technique using the hot water method established by Jodon (1938) and modified by Butany (1961) were released from 1964 and up to 1999, (Table 1). In addition, ten Japanese differential varieties (JVDs) and two International differential varieties (IDVs) were evaluated under field conditions at three locations i.e. Sakha, Gemmiza and Zarzora started from 1994 up to 2007 for blast resistance at seedling stage for major gene resistance with natural infection at blast nursery test. Seedbeds were prepared during the first week of July in each season and fertilized with nitrogen in the form of urea $(46.5 \% \mathrm{~N})$ at the rate of $60 \mathrm{Kg}$ nitrogen per feddan and manured $\left(8 \mathrm{~m}^{3}\right.$ farmyard manure /fed.) and prepared for seeding the varieties. Width of the seedbed was one meter and $10.5 \mathrm{~m}$ long, at the beginning and end of each seedbed. Five rows of Giza 159 (blast spreader) were sown, then five of the considered varieties, and again one row of the spreader, with $15 \mathrm{~cm}$ apart. Another five varieties were sown, followed by one row of the resistant check (Giza 181). The susceptible and resistant checks were sown alternatively, surrounding five of the considered varieties. The varieties were left exposed for natural blast infection at seedling stage. About forty-days from sowing, the 
typical blast lesions were scored, according to the standard evaluation system using 0-9 scale (IRRI 1996) as follows:

$$
\begin{aligned}
& 1-2=\text { resistant }(\mathrm{R}) \\
& 3=\text { moderately resistant (MR) } \\
& 4-6=\text { susceptible (S) } \\
& 7-9=\text { highly susceptible (HS) }
\end{aligned}
$$

\section{$B$ - Multi-location test (Trap varieties) :}

A multilocation test was conducted to evaluate the level of resistance of the tested materials at tillering and mature growth stages to blast infection, and to the new pathogens and pathotypes on different rice cultivars or single gene varieties. This test also served as an early monitoring system for the occurrence of infection at different locations and for defining the level of infection at each location.

Both infection severity and number of infected varieties were used as indicators to identify hot spots.

Fourteen Egyptian rice cultivars were nursered at breeding experimental field, the nursery was fertilized with $100 \mathrm{Kg} /$ fed $15 \%$ P2O5 and $60 \mathrm{Kg} 46.5 \% \mathrm{~N} /$ feddan incorporated into the dry soil. Thirty day-old seedlings were transferred for transplanting at different locations (18-22 locations) and distributed on demonstration farmers' fields at six rice governorates starting from 1996 up to 2007 rice growing seasons. The plot size was $1 \times 3 \mathrm{~m}$, and the plants were transplanted in rows with 3-4 plants /hill. The nitrogen fertilizer was used in the form of urea $(46.5 \% \mathrm{~N})$ at the rate of $60 \mathrm{Kg}$ nitrogen per feddan. Two third of the nitrogen dose was incorporated into the dry soil, while the last third was added thirty days after transplanting. Blast reaction was recorded during rice growing season at 20day intervals.

\section{2- Greenhouse test and race identification: a-Isolation of rice blast fungus: -}

Typical blast lesions were collected from multi-location (trap varieties) starting from 1994 to 2006 rice growing seasons. Single conidian isolates were generated by streaking conidia from sporulating lesions on $20 \%$ water agar (WA) for $24 \mathrm{hr}$., then germinated single conidia were picked and transferred to water agar for another $24 \mathrm{hr}$. The tip of a single hyphae was cut and grown on banana dextrose agar medium (200g banana $+15 \mathrm{~g}$ glucose $+20 \mathrm{~g}$ agar $/ 1000 \mathrm{ml}$ water) on a piece of sterile filter paper disc. When the filter papers were completely occupied by the fungal growth, the paper discs were individually transferred into Petri dishes. About one week later, the dried filter papers having the fungus isolates were cut into small pieces. Pieces obtained from each isolate were altogether introduced into a plastic vial and kept at $-20{ }^{\circ} \mathrm{C}$ for long - term storage (according to the technique of Mekwatanakarn et al. 1999).

\section{b-Pathogenicity and race identification:}

Pathogenicity tests and race identification studies were carried out for the obtained isolates. Eight international differential varieties namely: Raminad Str.3, Zenith, NP-125, Usen, Dular, Kanto, Cl 8970s and Caloro 
(Atkins et al., 1967) were used for identification of international races and ten Japanese differential varieties ( Shin 2, Aichi Asahi, Ishikari shiroke, Kanto 51, Tsuyake, Fukunishiki, Yashiro Mochi, Pi No.4, Toride 1, BL1) for identification of effective resistance genes. Seeds of each variety were seeded in plastic trays $(30 \times 20 \times 15 \mathrm{~cm}$.). Each tray comprised 10 rows representing eight international differential varieties and two susceptible checks (Giza 159 and Giza 171). The trays were kept in the greenhouse at $25-30^{\circ} \mathrm{C}$, and fertilized with Urea $46.5 \% \mathrm{~N}$ (5 g/tray). Seedlings were ready for inoculation at 3-4-leaf stage, about 3-4 weeks after sowing.

For spore production, isolates were individually grown on banana dextrose agar medium ( $200 \mathrm{~g}$ banana, $15 \mathrm{~g}$ glucose, $15 \mathrm{~g}$ agar/ $1000 \mathrm{ml}$ water) under florescent light for 10 days at $28{ }^{\circ} \mathrm{C}$ for spore production. The spores were harvested at a density of at least 25 spores / microscopic field, examined by $10 \times$ objective. Rice seedlings of about 20 -days old, in the trays, were inoculated by spraying with spore suspension $(100 \mathrm{ml})$ adjusted to $5 \mathrm{x}$ $10^{4} \mathrm{spores} / \mathrm{ml}$. Gelatin was added to the spore suspension at a concentration of $2.5 \mathrm{~g} / \mathrm{L}$ (Bastiaans, 1993) to enhance the adhesion of spores on leaf surfaces. Each isolate was sprayed using electrical spray gun. The inoculated seedlings were held in a moist chamber with at least $90 \%$ R.H. and $25-28{ }^{\circ} \mathrm{C}$ for $24 \mathrm{hr}$, and then moved to the greenhouse. Seven days after inoculation, blast reaction was recorded according to the standard evaluation system using 0-9 scale (IRRI 1996).

\section{Cultivars development:}

\section{RESULTS AND DISCUSSION}

Three varieties namely, Nahda, Giza 171 and Giza 172 were a basic varieties for varietal development in Egypt. Giza 171 and Giza 172, were used for the production of Giza 176 and Giza 177 which were used for releasing of Sakha 101 and Sakha 102. While, Giza 177 and Sakha 102 were used for developing Sakha 103 and Sakha104.

Disease management through resistant varieties is the ideal technique and good economical way to control blast disease. In this investigation, fourteen rice Egyptian cultivars were grown from 1994 to 2007. Table (1) showed that the cultivars Giza 171 and Giza 172 played a major role for developing new cultivars and were growing for more than 20 years. Nahda variety was a common parent for releasing Giza 171 and Giza 172, which were used for the production of Giza 177 and Giza 176 cultivars, that were used for releasing Sakha 101 and Sakha 102 cultivars. While, Sakha 101 and Sakha 102 were used for developing Sakha 103 and Sakha 104 cultivars. Giza 171 (Nahda/ Calady 40) and Giza 172 (Nahda/ Kinmaze) were released as new blast resistant cultivars and were cultivated in more than $85 \%$ of the growing rice area (Balal, 1978). These cultivars were broken down by blast disease in 1986. In 1984, Reiho variety was released as a new high yielding variety, but when cultivated in $25 \%$ of rice crop area, resistance was overcome at first year of release resulting in blast epidemic (Bonman and Rush, 1985). Rice breeding research program in Egypt in 
collaboration with rice pathology program aimed to develop rice varieties with different resistance genes to blast disease, with high yield. This lead to the production of the new cultivars i.e. Giza 177, Giza 178, Sakha 101, Sakha 102, Sakha 103, Sakha 104 and Giza 182. However, in the period of 1996-2000, there has been $30 \%$ increase in the production and $12 \%$ in the yield per hectare (RRTC, National report 2006).

Table (1): Cultivar duration to breakdown, parentage and yield of the tested cultivars.

\begin{tabular}{|l|c|c|c|l|l|}
\hline Cultivars & $\begin{array}{c}\text { Year of } \\
\text { release }\end{array}$ & $\begin{array}{c}\text { Number of } \\
\text { years } \\
\text { grown till } \\
\text { occurrance } \\
\text { breakdown }\end{array}$ & $\begin{array}{c}\text { Planted } \\
\text { area } \\
\text { (\%) }\end{array}$ & \multicolumn{1}{|c|}{ parentage } & $\begin{array}{l}\text { Yield } \\
\text { (t/ha) }\end{array}$ \\
\hline Giza159 & 1964 & 6 & 20 & Giza14 / AgamiM1 & 5.70 \\
Giza171 & 1975 & 20 & 55 & Nahda (Pure line selection) / Calady40 & 8.90 \\
Giza172 & 1977 & 14 & 30 & Nahda / Kinmaza & 8.60 \\
Reiho & 1978 & 5 & 25 & Exotic (Japan) & 8.10 \\
Giza181 & 1988 & Until now & 2 & IR28/IR22 & 9.20 \\
Giza175 & 1989 & Until now & 7 & IR28/IR1541//Giza180/Giza14 & 9.00 \\
Giza176 & 1991 & 6 & 15 & Galrose76 / Giza172 // Gz14 & 9.50 \\
Giza177 & 1995 & Until now & 40 & Giza171 / Yamji No.1 / /PiNo.4 & 9.90 \\
Giza178 & 1995 & Until now & 25 & Giza175 / Milyange49 & 11.07 \\
Sakha101 & 1997 & 7 & 20 & Giza176 / Milang79 & 11.85 \\
Sakha102 & 1997 & Until now & 10 & Gz4096-7-1 / Giza177 & 10.65 \\
Sakha103 & 1999 & Until now & 7 & Giza177 / Suwwon349 & 10.70 \\
Sakha104 & 1999 & 7 & 20 & Gz4096-8-1 / Gz4100-9-1 & 11.37 \\
Giza182 & 1999 & Until now & 0.5 & Giza181 / IR39422-163-247-2-2-3 & 11.25 \\
\hline
\end{tabular}

\section{Host Plant Resistance :}

The introduction of new resistant cvs. to the major rice diseases with good level of resistance is very important. Both major and minor genes are needed for more durability of resistance, especially for rice blast pathogen (Pyricularia grisea). Different test conditions were carried out:

\section{2-Field evaluation:}

\section{1 -Blast nursery test}

Twenty-six rice entries comprised fourteen Egyptian commercial rice cultivars, ten Japanese differential varieties and two international differential varieties were evaluated at seedling stage under blast nursery at three locations; i.e. Sakha, Gemmiza and Zarzora during 1994 up to 2007 growing seasons. Data in Table (2) indicated that some Egyptian rice cultivars namely Giza 171, Giza 172, Giza 176, Giza 159 and Reiho were completely susceptible or highly susceptible to blast. However, resistance of these cultivars were broken down before 1994 season. On the other hand, some Egyptian rice cultivars namely, Giza 175, Giza 177, Giza 178, Sakha 102, Giza 182 and Sakha 103 were complete resistance during this period. Giza 181 rice cultivar showed 
resistant during the evaluating period except in 2004, 2005 and 2006 seasons it showed some infection in one or two locations with 2-4 score reaction. Sakha 101 was resistant up to 2002 and started to be infected from 2003 and 2004 seasons in one or two locations with the appearance of specific race IG-1 as the blast score ranged from 2-5 and the cultivars became completely susceptible or highly susceptible from 2005 up to 2007 seasons from the disease. Concerning Sakha 104, it was infected in 1997 and 1998 in one or two locations and in 1999 in all three test locations by unknown blast race(s), and escaped during 2000 to 2002 seasons. It started to be completely susceptible from 2003 season with the appearance of its specific race IB- 45 .

Table (2): Type of infection of Egyptian cultivars and Japanese differential varieties from 1994 to 2007.

\begin{tabular}{|l|c|c|c|c|c|c|c|c|c|c|c|c|c|c|}
\hline varieties & $\mathbf{1 9 9 4}$ & $\mathbf{1 9 9 5}$ & $\mathbf{1 9 9 6}$ & $\mathbf{1 9 9 7}$ & $\mathbf{1 9 9 8}$ & $\mathbf{1 9 9 9}$ & $\mathbf{2 0 0 0}$ & $\mathbf{2 0 0 1}$ & $\mathbf{2 0 0 2}$ & $\mathbf{2 0 0 3}$ & $\mathbf{2 0 0 4}$ & $\mathbf{2 0 0 5}$ & $\mathbf{2 0 0 6}$ & $\mathbf{2 0 0 7}$ \\
\hline Giza171 & 6 & 7 & 7 & 7 & 7 & 7 & $4-7$ & $7-9$ & $7-9$ & $7-9$ & $4-7$ & 7 & $4-7$ & 7 \\
Giza172 & 7 & 6 & 7 & 8 & 7 & 7 & $\mathbf{4}-7$ & $5-7$ & $6-9$ & 7 & $4-6$ & 7 & $5-7$ & 7 \\
Giza175 & 2 & 3 & 2 & 2 & 2 & 2 & 2 & 2 & 2 & 2 & 2 & 2 & 2 & 2 \\
Giza176 & 6 & 8 & 7 & 7 & $4-8$ & $4-7$ & $4-7$ & 4 & $4-7$ & $4-7$ & $4-6$ & 7 & $4-6$ & 7 \\
Giza181 & 2 & 2 & 2 & 2 & 2 & 2 & 2 & 2 & 1 & 2 & $2-4$ & $2-4$ & $2-4$ & 2 \\
Giza177 & 2 & 2 & 2 & 2 & 2 & 2 & 2 & 2 & 2 & 2 & 2 & 3 & 2 & 2 \\
Giza178 & 2 & 2 & 2 & 2 & 2 & 2 & 2 & 2 & 1 & 2 & 2 & 2 & 3 & 2 \\
Sakha101 & 2 & 2 & 2 & 2 & 2 & 2 & 2 & 2 & 2 & $2-4$ & $2-5$ & $4-6$ & $4-6$ & 7 \\
Sakha102 & 2 & 2 & 2 & 2 & 2 & 2 & 2 & 2 & 2 & 2 & 2 & 3 & 2 & 2 \\
Giza182 & 1 & 2 & 1 & 2 & 2 & 2 & 2 & 2 & 2 & 2 & 2 & 2 & 2 & 2 \\
Giza159 & 8 & 7 & 7 & 6 & $4-7$ & $5-7$ & $5-7$ & $4-6$ & $4-6$ & $4-7$ & $5-7$ & $5-7$ & $4-6$ & 7 \\
Reiho & 7 & 6 & 6 & $2-7$ & 8 & $5-7$ & $4-6$ & $4-6$ & $5-6$ & $4-7$ & $4-5$ & $2-4$ & $4-6$ & $4-6$ \\
Sakha103 & - & 2 & 2 & 2 & 2 & 2 & 2 & 2 & 2 & 2 & 3 & 2 & 2 & 2 \\
Sakha104 & - & 2 & 2 & $2-4$ & $3-4$ & 4 & 2 & 2 & 2 & $2-5$ & $4-6$ & $4-6$ & $4-6$ & $4-7$ \\
& & & & & & & & & & & & & & \\
Toride 1 & $4-7$ & $4-6$ & 7 & $2-7$ & $2-4$ & 4 & $2-4$ & $2-5$ & $2-4$ & 4 & 4 & 4 & 5 & 5 \\
PiNo.4 & $2-5$ & $2-4$ & 2 & $4-7$ & $4-7$ & 5 & $4-6$ & 4 & 5 & $4-7$ & 5 & 6 & $4-6$ & $4-7$ \\
Shin2 & $4-7$ & $4-7$ & 7 & $3-7$ & 7 & 4 & 2 & 2 & 2 & 4 & 2 & $2-7$ & 2 & 2 \\
BL1 & 2 & 2 & 2 & 2 & 3 & 2 & 2 & 2 & 3 & 2 & $2-4$ & $2-4$ & $2-5$ & $2-4$ \\
Kanto 51 & 2 & 2 & $2-4$ & $2-3$ & 2 & 2 & 2 & 2 & 2 & 3 & 2 & 4 & 4 & $4-5$ \\
Tsuyuake & $2-4$ & $2-4$ & 5 & $2-5$ & $2-4$ & 4 & 2 & $2-5$ & 4 & $3-4$ & $4-6$ & 5 & 5 & $4-7$ \\
Fuknishki & 2 & 3 & $3-4$ & 3 & $2-4$ & 1 & 2 & 2 & 2 & 3 & 2 & $2-5$ & $2-4$ & 2 \\
Aichiasahi & $7-8$ & $4-9$ & $4-8$ & 7 & $5-7$ & 5 & $5-6$ & 6 & 4 & 6 & $4-6$ & 7 & 6 & $4-6$ \\
Zenth & 2 & 3 & 3 & 2 & 3 & $2-4$ & 2 & 2 & 2 & 2 & 3 & 2 & 4 & 2 \\
Dular & 2 & 3 & 2 & 3 & 2 & 2 & $2-4$ & $2-4$ & 4 & 2 & 2 & 2 & 2 & 2 \\
Yashiromuchi & $5-7$ & 5 & $4-8$ & 7 & $5-7$ & $5-8$ & $4-6$ & $2-4$ & 5 & $2-5$ & $2-5$ & 7 & 6 & $4-5$ \\
Ishikarishiroke & $5-7$ & 7 & $4-7$ & $4-7$ & $2-4$ & $4-5$ & 2 & 2 & 2 & 2 & 2 & 5 & 5 & $2-3$ \\
\hline
\end{tabular}

For the international and Japanese differential varieties, data in Table (2) revealed that all the evaluated rice varieties had a segregated reaction with resistant to susceptible in one, two or all locations. While, Toride 1 and $\mathrm{Pi}$ No.4 were susceptible in all locations except were escaped in some seasons in one, two or all locations during evaluation period. Reaction of rice to blast was usually higher at the seedling stage (blast nursery and greenhouse tests) than at field reaction at tillering stage (multiplication test). This may be due to leaf age, since rice plants 
were younger in the blast nursery and greenhouse than in the field test (Roumen 1992, Roumen et al 1992, Aidy et al 1994).

\section{2 -Multi-location test:}

A multilocation test was conducted to evaluate the level of resistance of the tested materials at tillering and mature growth stages and to isolate any new pathotype on promising lines or single-gene varieties. This test worked also as an early monitoring system for the occurrence of infection at different locations and level of infection at each location. (Sehly, et al., 2000).

Fourteen Egyptian commercial rice cultivars were evaluated at adult stage in 18-22 locations distributed at six rice governorates from 1996 up to 2007 growing seasons. Data in Table (3) show that Giza 171, Giza 159, Giza 176 and Reiho rice cultivars were susceptible in most of the tested locations and ranged from 54.5 to $91 \%, 33.3$ to $100 \%, 23.8$ to 100 and 17 to $90 \%$ in some locations, respectively. Giza 181, Giza 177, Giza 178, Sakha 102, Giza 182 and Sakha 103 were completely resistant at all tested locations during this period. Sakha 101 and Sakha 104 were resistant up to 2003 and susceptible in $15 \%$ of the tested locations starting from 2004 season, and their percentages of infected locations with susceptible reaction increased to 47.6, 85.7 and $72.2 \%$ in 2005,2006 and 2007 respectively. While Sakha 104 started to be broken down in 2004 and recorded a susceptible reaction in $15 \%$ of all tested locations and this percentage increased to 28.6, 66.7 and 44.4\% in 2005, 2006 and 2007, respectively. Giza 172 and Giza 175 were not tested throughout 2002 to 2007 season, (Table 3). Sehly et al. (2002) reported that some entries were resistant at all locations, while some other commercial cultivars were susceptible at all locations. Only few entries showed slight susceptible (type-4 lesion). This may indicate the existence of new pathotype(s) in such locations. In addition, high severity of infection and high number of infected entries at a location may indicate a high inoculum level in the area and more frequent pathotypes. According to Imbe (1998) the Egyptian varieties carried different blast resistance genes (Table 4). The genes Pi-a, Pi-ks, Pi-z and even unknown genes in Giza 171, Giza 172 and Giza 176 were ineffective under Egyptian condition because these varieties were highly susceptible to blast disease. $\mathrm{Pi}$-a gene showed resistant level ranging from 14.3 to $20 \%$ and Pi-Ks showed 30.7 to $85 \%$ during 1994 up to 2003 seasons (Table 5). While, the Egyptian resistant varieties Giza177, Giza178, Sakha102, Giza182 and Sakha103 were resistant and carrying different resistance genes (Table 4). Concerning Sakha 101, it has Pita2 according to Imbe (1998) with low level of resistance ranging from 21.1 up to $70 \%$ from 1997 up to 2006 seasons, these were the same period of its release and breakdown (1999 to 2003 seasons). 
Table (3): Percentage of locations with susceptible reaction to blast infection of commercial Egyptian rice cultivars cultivated in 18 to 22 multi-location test at six rice governorates.

\begin{tabular}{|l|c|c|c|c|c|c|c|c|c|c|c|c|}
\hline \multicolumn{1}{|c}{ Cultivars } & $\mathbf{1 9 9 6}$ & $\mathbf{1 9 9 7}$ & $\mathbf{1 9 9 8}$ & $\mathbf{1 9 9 9}$ & $\mathbf{2 0 0 0}$ & $\mathbf{2 0 0 1}$ & $\mathbf{2 0 0 2}$ & $\mathbf{2 0 0 3}$ & $\mathbf{2 0 0 4}$ & $\mathbf{2 0 0 5}$ & $\mathbf{2 0 0 6}$ & $\mathbf{2 0 0 7}$ \\
\hline Giza171 & 90 & 85.7 & 54.5 & 80 & 80 & 85 & 88.9 & 83.3 & 90 & 91 & 85.7 & 74.7 \\
\hline Giza172 & 90 & 95.2 & 54.5 & 70 & 70 & 48 & $\mathrm{NT}$ & $\mathrm{NT}$ & $\mathrm{NT}$ & $\mathrm{NT}$ & $\mathrm{NT}$ & $\mathrm{NT}$ \\
\hline Giza175 & 0 & 0 & 0 & 0 & 0 & 0 & $\mathrm{NT}$ & $\mathrm{NT}$ & $\mathrm{NT}$ & $\mathrm{NT}$ & $\mathrm{NT}$ & $\mathrm{NT}$ \\
\hline Giza176 & 100 & 66.7 & 31.8 & 70 & 75 & 85.7 & 88.9 & 83.8 & 90 & 33.3 & 81 & 74.7 \\
\hline Giza181 & 0 & 0 & 0 & 0 & 0 & 0 & 0 & 0 & 0 & 0 & 0 & 0 \\
\hline Giza177 & 0 & 0 & 0 & 0 & 0 & 0 & 0 & 0 & 0 & 0 & 0 & 0 \\
\hline Giza178 & 0 & 0 & 0 & 0 & 0 & 0 & 0 & 0 & 0 & 0 & 0 & 0 \\
\hline Sakha101 & 0 & 0 & 0 & 0 & 0 & 0 & 0 & 0 & 15 & 47.6 & 85.7 & 72.2 \\
\hline Sakha102 & 0 & 0 & 0 & 0 & 0 & 0 & 0 & 0 & 0 & 0 & 0 & 0 \\
\hline Giza182 & 0 & 0 & 0 & 0 & 0 & 0 & 0 & 0 & 0 & 0 & 0 & 0 \\
\hline Giza159 & 100 & 95.2 & 100 & 90 & 90 & 76.2 & 77.8 & 94.4 & 100 & 66.7 & 23.8 & 16.7 \\
\hline Reiho & 90 & 85.7 & 40.9 & 65 & 55 & 61.9 & 77.8 & 17 & 90 & 19 & 33.3 & 22.1 \\
\hline Sakha103 & 0 & 0 & 0 & 0 & 0 & 0 & 0 & 0 & 0 & 0 & 0 & 0 \\
\hline Sakha104 & 0 & 0 & 0 & 0 & 0 & 0 & 0 & 0 & 15 & 28.6 & 66.7 & 44.4 \\
\hline
\end{tabular}

Table (4): Blast resistant genes in Egyptian cultivars estimated and suggested according to (Imbe 1998).

\begin{tabular}{|c|c|}
\hline variety & Gene \\
\hline Giza171 & $P i-a, P i-k^{s}$, unknown gene (s) \\
\hline Giza172 & Pi-a, Pi-ks, unknown gene (s) \\
\hline Giza175 & Unknown \\
\hline Giza176 & $P i-z, P i-a, P i-K^{s}$, unknown (s) \\
\hline Giza181 & $P i-20, P i-b, P i-k^{s}$ \\
\hline Giza177 & Pi-ta2*, Pi-sh \\
\hline Giza178 & Pi-i (Pi 3), unknown gene (s) \\
\hline Sakha101 & $P i-t a^{2 *}$ \\
\hline Sakha102 & $P i-t a^{2 *}+P i-i, P i-s h$ \\
\hline Giza182 & Unknown \\
\hline Giza159 & Unknown \\
\hline Reiho & $P i-t a^{2}, P i-a$ \\
\hline Sakha103 & Unknown \\
\hline Sakha104 & Unknown \\
\hline
\end{tabular}

\section{3- Effective resistant genes:}

Data representing the main level of resistance for Japanese differential varieties genes during 1994-1996 period are presented in Table (5). Lower levels for Pi-a in Aichi Asahi and Pi-ks in Shin2 with 20 and $31 \%$, while higher level of resistance for $P i-b$ in BL1 followed by Pi$k$ in Kanto 51 and Pi-m in Tsuyake with 90,85 and $80 \%$. The level of rest resistant genes ranged from 45 to $76 \%$. For the second period i.e. 1997 up to 2000, Pi-z in Fukunishiki followed by Pi-K in Kanto 51 with 95.6 and $93.4 \%$, while Pi-a in Aichi Asahi still the lower level one with $14.3 \%$ followed by $\mathrm{Pi}_{\mathrm{ta}}{ }^{2}$ in Pi No.4 with $21.1 \%$. For the period of 2001 to 2004 , the resistance levels for all Japanese differential varieties 
genes ranged from 60 to 95\% except $\mathrm{Pi}$-a and $\mathrm{Pi}$-ta ${ }^{2}$ with 15 and 25\%, respectively (Table 5). Sehly et al., (2002) evaluated 20 isolates of Pyricularia grisea on Japanese differential varieties, each with a specific major genes for blast resistance, the isolates were representing the six rice-growing governorates. $P i-Z^{t}$ in Toride $1, P i-z$ in Fukunishiki, $P i-b$ in $\mathrm{BL} 1$, and Pi-k in Kanto 51 were completely resistant against the 20 tested isolates. Pi-ta in Yashiro Mochi, Pi-ks in Shin 2, and Pi-a in Aichi Asahi showed 80,90 and $100 \%$ susceptibility to the tested isolates. However, $\mathrm{Pi}^{-\mathrm{k}^{m}}$ in Tsuyake and $\mathrm{Pi}-\mathrm{i}$ in Ishikari Shiroke showed moderate level of resistance, with 40 and $60 \%$ susceptibility, respectively. In addition, they observed before in 1988 season that $P i-Z^{t}$ in Toride 1 was moderately resistant (46.7\% resistance) against the 30 isolates of $P$. oryzae. Pi-z in Fukunishiki, Pi-k in Kanto 51, Pi- $\mathrm{k}^{m}$ in Tsuyake, and Pi-b in $B L 1$ showed $86.7,90,93.3$, and $96.7 \%$ resistance against 30 tested isolates, respectively. Highly susceptible genes $\mathrm{Pi}-\mathrm{k}^{s}$ in Shin 2 and $\mathrm{Pi}$-a in Aichi Asahi had 23.3 and $33.3 \%$ resistance, respectively. Eizenga et al., (2006) screened 91 accessions for presence of the R-genes, out of these entries five Egyptian entries i.e. Egyptian yasmine, GZ 1368-5-4 and GZ 5594-23-1-2 have Pi-b and Pi-ta, while GZ 5578-2-1-2 has Pi-ta, $\mathrm{Pi}-\mathrm{K}^{\mathrm{s}}$, and $\mathrm{Pi}-\mathrm{Z}$ genes, $\mathrm{GZ}$ 5830-48-2-2 has $\mathrm{Pi}-\mathrm{b}$ and $\mathrm{Pi}-\mathrm{K}^{\mathrm{s}}$.

Table (5): levels of resistance of blast resistant genes in japanese differential varieties to Egyption isolates of Pryicularia grisea inoculated under greenhouse test, Sakha (20 isolates each season in the period of 1994-1996 and 140 isolates in the period of 1997-2004).

\begin{tabular}{|l|c|c|c|c|}
\hline \multirow{2}{*}{$\begin{array}{c}\text { Japanease differential } \\
\text { variety }\end{array}$} & \multicolumn{4}{|c|}{ \% of resistance } \\
\cline { 2 - 5 } & Pi- Genes & $\mathbf{1 9 9 4 - 1 9 9 6}$ & $\mathbf{1 9 9 7 - 2 0 0 0}$ & $\mathbf{2 0 0 1 - 2 0 0 4}$ \\
\hline 1- Shin 2 & $P i-k^{s}$ & 31 & 30.7 & 85 \\
\hline 2- Aichi Asahi & $P i-a$ & 20 & 14.3 & 15 \\
\hline 3- Ishikari shiroke & $P i-i$. & 53 & 92 & 80 \\
\hline 4- Kanto 51 & $P i-k$ & 85 & 93.4 & 95 \\
\hline 5- Tsuyake & $P i-m$ & 80 & 79.3 & 85 \\
\hline 6- - Fukunishiki & $P i-z$ & 75 & 95.6 & 90 \\
\hline 7- Yashiro Mochi & $P i-t a)$ & 45 & 39.9 & 80 \\
\hline 8- Pi No.4 & $P i-t a^{2}$ & 56 & 21.1 & 25 \\
\hline 9- Toride 1 & $P i-Z^{t}$ & 76 & 77.1 & 60 \\
\hline 10- BL1 & $P i-b$ & 90 & 67.6 & 85 \\
\hline
\end{tabular}

\section{Common race Identification:}

Rice blast fungus, $P$. grisea is known to be highly variable. Many investigators studied the physiological races of the fungus in different rice-growing countries (Atkins 1962, Yamada 1985).

More than two hundred blast isolates collected from rice growing governorates during 1994 to 2006 were identified according to their reaction on the international differential varieties in the greenhouse under artificial inoculation conditions. The results in Table (6) show that during 1994 up to 1996, IC group followed by IB, ID and IG groups were 
the common races representing $32.5,15,15$ and $12.5 \%$, respectively, while IE, IF, IH and II represented 7.5, 7.5, 5.0 and 3.3 respectively, the group IA was absent. During 1997 up to 2000 period, all groups were represented, and IH and IG groups were the common races representing 29.6 and $25.8 \%$ respectively, while the rest groups ranged from 1.1 to $16.3 \%$. During the third period (2001 up to 2004), the IG-1 common race represented $50 \%$ and it was specific on Sakha 101 rice cultivar and responsible for its breakdown. On the other hand, IB group which included IB-45 race as a specific race for Sakha 104 and also responsible for its breakdown and each of IC, ID, IF and IH representing $10 \%$ for each, while each of IA, IE, and II were absent in this period. The last period (2005 and 2006 seasons) still IG group was the common race followed by IB and ID groups representing $20 \%$ for each. IC and IF groups were representing $10 \%$ for each, while, IA, IE, IH and II groups were absent in this period. Bidaux (1976) and Notteghem (1981) observed that virulent strains existed for all the identified genes of vertical resistance and most of the strains possessed virulent genes, which were not necessary for their survival. Sehly et al (2000) inoculated forty-five isolates of $P$. grisea inoculated on eight international differential varieties. The most common races were $\mathrm{IH}-1$ (36. 6\%), I D-race group (17.8\%), I A (13.3\%), I G-1 (13.3\%) and avirulent race group II (9.0\%). In Egypt, El-Kazzaz (1973) identified 5 races from 10 isolates as IB-47, IC-17, IF-3, IH-1, and II- 1 . Abdel-Hak (1981) identified IA-13, IB-55, and IC-5 in 1975 season; 10 races were identified in 1977. Kamel et al. (1985) recorded 31 races from 121 isolates of $P$. oryzae. IR28,IR 50, and IR 1626-203 and Giza 180 were found resistant to all tested races, while Giza 159 and Reiho were susceptible to almost all races, except II. Sehly et al. (1993) identified 60 isolates collected in 1989, 1990, and 1991 seasons on international differential varieties with 20 isolates in each season. Five race groups were identified in the three seasons, including IC, ID, IG, IH and II. Races identified in 1989 were IG (35\%), IH1 (30\%), IC29 and IC25 $(20 \%)$, ID5 (10\%), and II (5\%). In 1990 season, ID13 and ID15 represented $55 \%$ of the isolates; IC $17, \mathrm{IC} 25$, and IC29 (40\%); and IH1 (5\%). In 1991 season, ID13 and ID15 represented $40 \%$ of the isolates; IH1 (25\%); IG1 (20\%);I and IC3, IC13 and IC21 (15\%). These results are agreement with the findings of Sehly et al (2002) who showed the distribution of races at the different governorates. Moldenhauer et al.(1992) evaluated nine parents to rice blast races IB-49 and IC-17. The mode of inheritance to rice blast fungus races IC-17 and IB-49 for the resistant parents (Race IC-17: Mars, Zenith, Katy, Raminad strain 3 and Pi No.4; Race IB-49: Katy, Raminad strain 3 and Pi No.4) is in general, dominant and monogenic in nature. Two complementary genes for resistance to race IB-49 are evident in the resistant parent NP125.Wang et al. (2007) inoculated 141 rice entries with blast race IC17 to verify the presence of Pi-ta gene, 41 accessions were resistant to IC-17, to verify the presence and absence of the Pi-ta gene, two additional DNA markers that amplify different parts of the Pi-ta gene, 20 
rice accessions containing cultivars that were resistant to IC-17 must be due to other R-genes.

Table (6): Common races of Pyricularia grisea identified through 19942006 period as percent of occurrence

\begin{tabular}{|c|c|c|c|c|}
\hline \multirow{2}{*}{ Race group } & \multicolumn{4}{|c|}{ Mean percent of occurrence } \\
\hline & 1994-1996 & $1997-2000$ & 2001-2004 & $2005-2006$ \\
\hline IA & - & 6.7 & - & - \\
\hline IB & 15.0 & 8.3 & 10 & 20 \\
\hline IC & 32.5 & 5.2 & 10 & 10 \\
\hline ID & 15.0 & 16.3 & 10 & 20 \\
\hline $\mathrm{IE}$ & 7.5 & 2.5 & - & - \\
\hline IF & 7.5 & 1.1 & 10 & 10 \\
\hline IG & 12.5 & 25.8 & 50 & 40 \\
\hline $\mathrm{IH}$ & 5.0 & 29.6 & 10 & - \\
\hline II & 3.3 & 4.5 & - & - \\
\hline $\begin{array}{l}\text { Common } \\
\text { race }\end{array}$ & $\begin{array}{c}\text { IE-7,ID- } \\
15, \mathrm{IF}-4, \mathrm{IC}- \\
13, \mathrm{IH}-1 \\
\text { and II }\end{array}$ & $\begin{array}{c}\mathrm{IH}-1, \mathrm{IG}-1, \\
\mathrm{IA-109,} \text { ID- } \\
13 \text { and IC- } \\
13\end{array}$ & $\begin{array}{c}\text { IG-1*, IB- } \\
45^{\star *}, \mathrm{IH}- \\
1, \mathrm{IC}-31 \text { and } \\
\text { ID-3 }\end{array}$ & $\begin{array}{c}\text { IG-1,IB-45, } \\
\text { ID-15 and } \\
\text { IC-13 }\end{array}$ \\
\hline
\end{tabular}

\section{REFERENCES}

Abdel-Hak, T.M. (1981). Rice diseases assessment of their impact in Egypt. Proc. $1^{\text {st }}$ National Rice Institute Conference, Feb. 21-25, 1981: 114121.

Abo-Yossef, M.I. and S.M. El-Wahsh (2005). Screening of some hybrid and inbred rice varieties for allelopathic activity and blast resistance. Egypt. J.Agric. Res. 83(5B): 539-548.

Aidy, I.R.; A.E. Draz and M.R. Sehly. (1994). Rice varietal resistance to blast disease under different test conditions. Proc. $6^{\text {th }}$ Conf. Agron., AlAzhar Univ., Cairo, Egypt, Vol. 1, Sept. 1994: 223-230.

Atkins, J.G. (1962). Prevalence and distribution of pathogenic races of Pyricularia oryzae in the US. Phytopathology, 52: 2. (Abs).

Atkins, J.G., A. L. Robert, C. R. Adair, K. Goto, T. Kozako, R.Yanagida, Y. Yamada and S. Matsumoto (1967). An international set of rice varieties for differentiating races of Pyricularia oryzae. Phytopathology, 57: 298301.

Balal, M.S. (1978). Achievements in rice research and production in Egypt. Technology for Improving Food Production. Pages 564-567 in Proceedings of the FAO-SIDA Seminar, Lahre, Pakistan.

Bastiaans, L. (1993). Effects of leaf blast on photosynthesis of rice.1- Leaf photosynthesis. Netherlands Journal of Plant Pathology 99: 197-203.

Berg, D.E. and M.M. Howe (1989). Mobile elements. Am Soc of Microbiology Washington, DC. 
Bidaux J.M. (1976). Screening for horizontal resistance to rice blast Pyricularia oryzae in Africa Academic Press, London, 159-172.

Bonman, J.M. and M.C. Rush (1985). Report on rice blast in Egypt. Pages 99-104 in the rice research and training project in Egypt. U. of California Printing Dept., Berkeley. 120 p.

Butany, W.T. (1961). Mass emasculation in rice. Intern. Rice com. Newsletter. 9: 9-13.

Coley, R.(1992). Blast: a variable and dangerous disease. Rice J 95(3): 9-11.

Crawford, M.S.; F.G. Chumley; C.G. Weaver and B. Valent (1986). Characterization of heterokayotic and vegetative diploid phases of Magnoaporthe grisa. Genetics 114:1111-1129.

Eizenga, G.C., H.A. Agrama, F.N. Lee, W. Yan and F.N. Lee (2006). Identifying novel resistance genes in newly introduced blast resistant rice germplasm. Crop Sci. 46: 1870-1878.

El-Kazzaz, M.K. (1973). Studies on the diseases affecting rice crop in Egypt. Ph.D. Thesis, Faculty of Agric. Alex. Univ.

Giatgong, P. and R.A. Fredericksen (1969). Pathogenic variability and cytology of monoconidial subcultures of Pyricularia oryzae. Phytopathology 59: 1152-1157.

Imbe, T. (1998). Identification genes for blast resistance in some Egyptian rice varieties. Personal communication.

IRRI (1996). Standard evaluation system for rice. $3^{\text {rd }}$ ed. International Rice Research Institute, Los Banos, Philippines.

Jodon, N.E. (1938). Experiments on artificial hybridization of rice. J Amer. Soc. Agron. 30: 249-305.

Kamel, S.E.; T.M.A. El-Bigawii; M.R. Sehly and A.M. Saleh. (1985). Plant Pathology Program. Fourth National Rice Conference, March 1985, Cairo, Egypt.

Kistler, H.C. and V.P.W. Miao (1992). New modes of genetic exchange in filamentous fungi. Ann Rev Phytopathology 30: 131-152.

Mekwatanakarn, P.; W. Kositratana; T. Phromraksa and R.S. Zeigler (1999). Sexually fertile Magnaporthe grisea rice pathogens in Thailand. Plant Disease. 83: 939-943.

Moldenhauer, K.A.K., A. O. Bastawisi and F.N. Lee (1992). Inheritance of resistance in rice to race IB-49 and IC-17 of Pricularia grisea rice blast. Crop Sci. 32: 584- 588.

Notteghem J.L. (1981). Analyse resultats dinoculation de 67 varieties de riz par 15 souches de Pyricularia oryzae. In Proceeding of the symposium on rice resistance to blast, IRAT, Montpellier, pp:301-318.

Ou, S.H. (1985). Rice diseases, Second edition, Commonwealth Agricultural Bureaux, Central Sales, Franham Royal, UK, 380 pp.

Rice Research and Training. Center, Sakha, Kafer El-Sheikh Egypt. (2006). National report.

Roumen, E.C. (1992). Effect of leaf age on components of partial resistance in rice to leaf blast. Euphytica. 63, 271-279. 
Roumen, E.C.; J.M. Bonman and J.E. Parlevlict. (1992). Leaf age related partial resistance to $P$. oryzae in tropical lowland rice cultivars as measured by the number of sporulating lesions. Phytopathology. 82: 1414-1417.

Row, K.V.; J.R. Aist and J.P. Crill (1985). Mitosis in the rice blast fugus and its possible implications to pathogenic variability. Canadiv $\mathrm{J}$ Bot 63 : 1129-1134.

Sehly, M.R., Z.H. Osman, and E.A. Salem (2002). Rice diseases. In: Rice in Egypt, pp 301.

Sehly, M.R., Z.H. Osman, H.A. Mohamed and A.O. Bastawisi (1990). Reaction of some rice entries to Pyricularia oryzae Cav. and race picture. In: Sixth Congress of Phytopathology, March, 5-7, Cairo, Egypt, $154-170$.

Sehly, M.R.; Z.H. Osman; I.A. Salem; I.R. Aidy and A.E. Draz. (1993). Multilocation test for rice blast reaction in relation to race distribution. Egypt. J. Appl. Sci., 8(2): 136-152.

Sehly. M. R.; Osman, Z. H.; Salem E. A., Badr, E. A. S. and S. M. El- Wahsh (2000). Proceeding of the Fourth. National Rice Research and Development Program Workshop 12-13 Feb., 2000: 73-115.

Shinza Koizumi (2006). Durability of resistance to rice blast disease. Differential system for Blast Resistance for a Stable Rice Production Environment, IRRI Japan-JIRCAS collaborative workshop, Los Banos, Laguna, Philippines, August 2006.

Talbot, N.J.; Y.p. Salch; M. Ma and J.E. Hamer (1993). Karyotypic variations within clonal lineages of the blast fugus Magnaprrthe grisea. App Env Micrbiology 59: 585-593.

Veillet, S. M., C. Filippi and A. Gallais (1996). Combined genetic analysis of partial blast resistance in an upland rice population and recurrent selection for line and hybrid values. Theor, Appi. Genet., 92: 644-653.

Wang, Z., Y. JIA, J.N. Rutger and Y. Xia (200V). Rapid survey for presence of a blast resistance gene Pi-ta in rice cultivars using the dominant DNA markers derived from portions of the Pi-ta gene. Plant Breeding $126,36-42$.

Yamada, M. (1985). Pathogenic specialization of rice blast fungus in Japan. (Emvironment Div. Hokuriku Natn. Agric. Exp. Sta. Inada, Joetsu, Niigata 249-01 Japan). TARO, 1985. 19(3): 178-183.

Yamaguchii, M.; H. Saitoh and T. Higashi (1998). Effect of varietals field resistance for control of rice blast. Advances in rice blast research, 197-202. Kluwer Academic Publishers, Netherlands. 


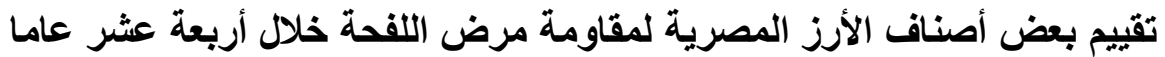

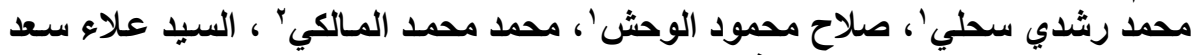

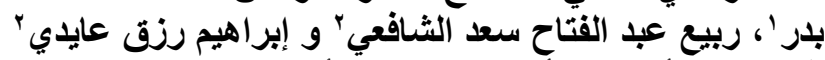

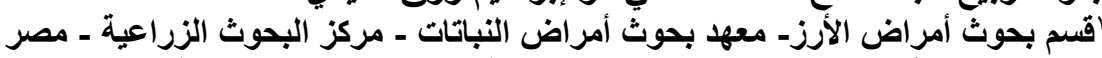

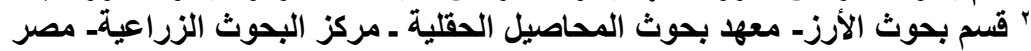

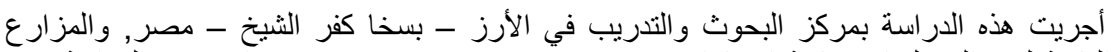

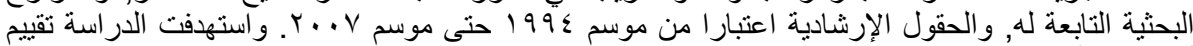

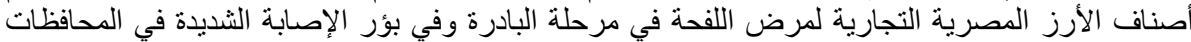

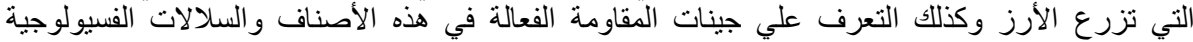

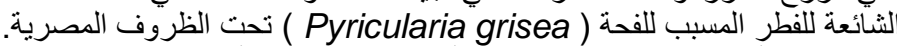

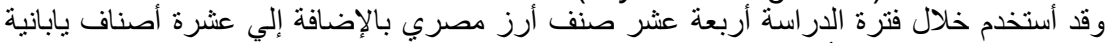

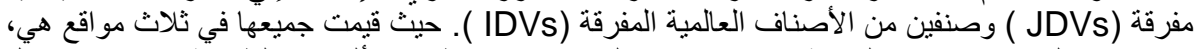

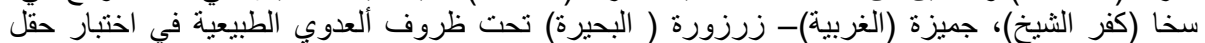

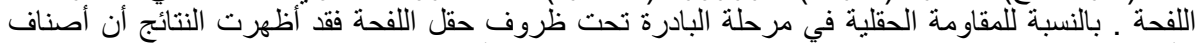

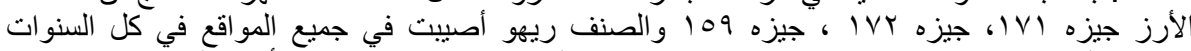

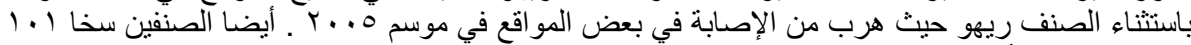

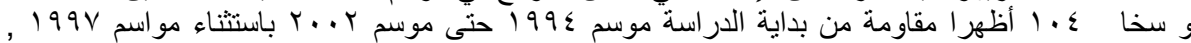

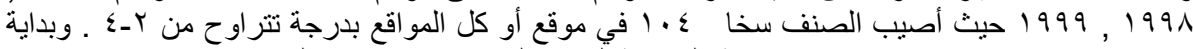

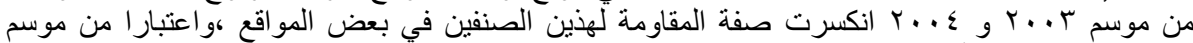

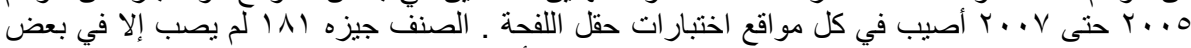

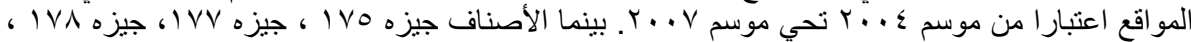

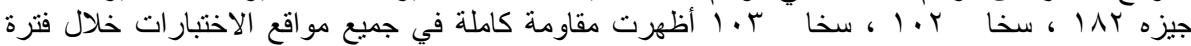

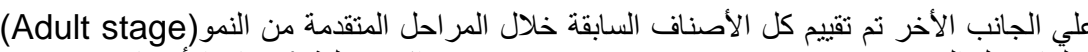
الار اسة.

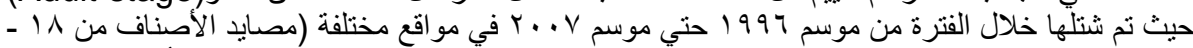

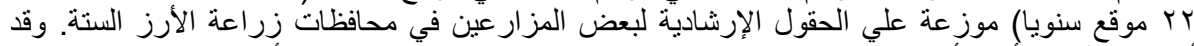

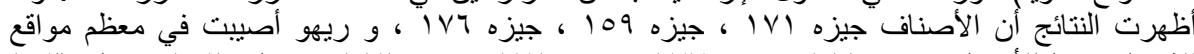

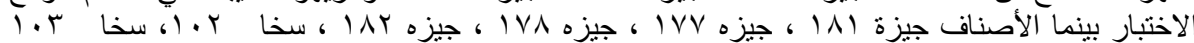

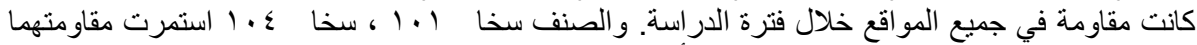

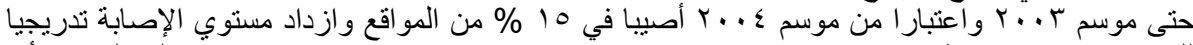

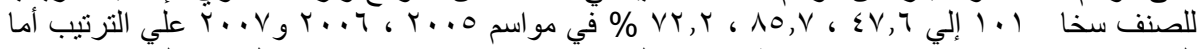

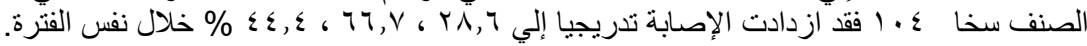

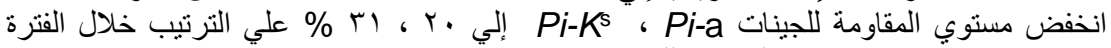

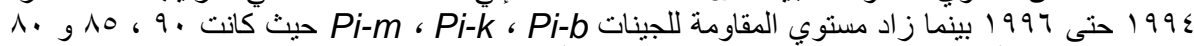

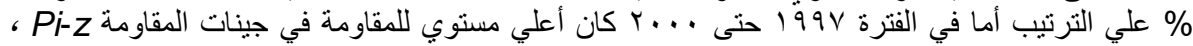

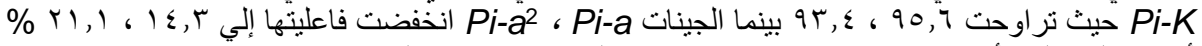

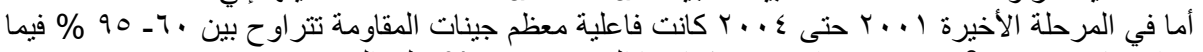

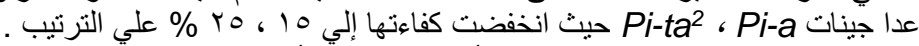

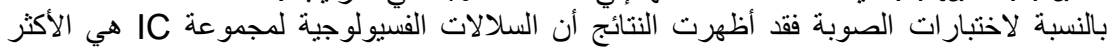

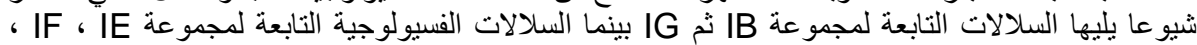

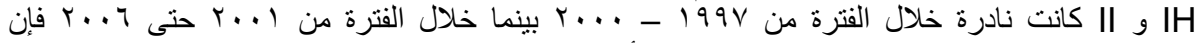

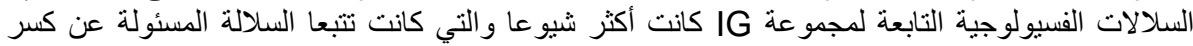

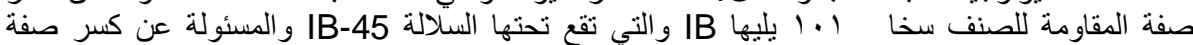

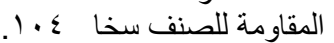

